\title{
メンブランフィルターによる清酒火落菌の 濾過除菌について
}

\author{
鈴木明治*・松岡正幸・土崎 南・斉藤 豊 \\ (北興化学工業(株)中央研究所)
}

昭和 46 年 8 月 18 日受理

\begin{abstract}
3 種ニュークリポアメンブランフィルター**（以下NPフィルターと略称する）孔径 0.6 ミクロン (GE-60 と称する)，0.4ミクロン（GE-40）和上び 0.2 ミクロン（GE-20）用いて清酒火落菌の濾過除 菌試験を行なった。試験に供した火落菌は $\mathrm{H}-1, \mathrm{H}-7, \mathrm{H}-34, \mathrm{~S}-14, \mathrm{~S}-24, \mathrm{~S}-34$ 呿よび 9006 の 7 菌株である。GE-60 は全菌株の通過を許したが，GE-40 扔よび GE-20はぞの菌株も完全に捕捉し て, その濾液を密封状態で 3 ケ月間, $30^{\circ} \mathrm{C}$ で保存したが火落菌の発育, 增殖は認められなかった。

清酒火落菌の滤過除菌にNPフィルター，特飞 GE-40 は十分使用し得るるのである。同時飞行な ったN Pフィルター濾過処理による清酒の物性的変化の試験に於いて, 濾過清酒に異常は認められな かった。
\end{abstract}

\section{緒䨐}

清酒酾造に於ける最大の厄災は, 清酒の火落ちである。 その原因となる火落菌の研究は明治初期に英国人ATKI$\mathrm{NSON}^{1)}$ 飞上る火落菌の発見, 鳥居 ${ }^{2,3)}$ 飞上る火落酒中上 りの単離を源とし，以後幾多の先達に上る多くの優れた 研究4 31)がある。これら菌学的研究に伴ない, 火落ち防 除に関する研究も, 加熱殺菌 ${ }^{32,33)}$ (火入れ), 化学薬品添 加 ${ }^{34 \sim 22)}$, 及び抗生物質添加等 ${ }^{43,44)}$ の方面よりなされてい る。その中でつい最近まで拡く行なわれて来たのはサリ チル酸添加法であるが現在は火入れによる加熱殺菌法が それにとって代っている。サリチル酸添加法は規定最大 量である $250 \mathrm{ppm}$ を添加しても必ずしも十分ではない

* 東京農業大学锼造学科

** N P フィルターはポリカーボネートの薄膜（10ミク ロン）飞中性子を照射して創り出された飛跡を, あ る種の化学薬品処理によりエッチングし均一な孔径 を有するシリンダー状の孔を一平方センチィートル 当り 10 億個まで穿孔して作られたメンブランフィ ルターである。

孔径が均一でかつシリンダー状である事より逆洗 滌が可能であり, 従って連続使用が可能である。素 材の材質より物理的, 化学的飞安定であり, 滤液中 飞素材の溶出は無く, $120^{\circ} \mathrm{C}, 20$ 分間のオートクレ ーブ殺菌を行なっても何等変化が無い，これらの諸 性質より N P フィルターは飲料品の濾過飞は理想的 なフィルターと考完られる。
との報告 38 ,39) もあったがコストも安く，最良の火落防除 法として明治時代より使用されて来ていたが，ここ数年 来, 飲食料品飞防腐剤剂等の薬品を添加する事は世評の 反対が強く, 自肃する方向にある。サリチル酸は早急に 排泄され人体に影響を与えないという報告45) る市るが， 酒造業界は昭和 44 酒造年度生産清酒からサリチル酸使 用の自菊を申し合わせ，無サリ時代といら言葉と共にサ リチル酸添加法は火入れによる加熱殺菌法に代った。火 入れによる方法は熱処理時に酒精の蒸散 ${ }^{46)}$ があり, 色度 に変化をもたらし，かつコストが高いといら久点と耐熱 性火落菌 ${ }^{47}$ の出現等の問題を有する。このような状態の 火落ち防除の中で, 清酒の質を変えず低コストで完全 飞防除出来る方法の開発は望まれている。

最近米国に於いて, ビール, ワイン等酾造品の濾過除 菌にメンブランフィルターが使用されて来て捅り，この 使用に上る濾過除菌は濾液の変質, 変性が無く, 低コス トであるといら大きな利点を有し，ビール安定化には， 加熱殺菌, 薬剤添加（主として $n$-Heptyl p-hydroxybenzoate) 次ぐ第 3 の方法として注目されている。無変 質, 低コスト拉よび完全性といら事は清酒火落菌の濾過 除菌に応用出来得るものと考兄られる。

そこで著者等は, 最近, 米国ゼネラルエレクトリック 社によって開発された, ニュークリポアメンブランフィ ルターGE-60，GE-40 特よび GE-20 を用いて清酒火 落菌の滤過除菌試験, 濾過流量試験を行ない, かつ濾過 
鈴木・松周・土崎・斉藤 : メンブランフィルターによる清酒火落菌の濾過除菌について

といら物理的操作が清酒に与える影響について各種物性 試験を行なったので報告する。

\section{実験および結果}

\section{1. 火落菌濾過除菌試験}

1-1. 供試火落菌株

火落性乳酸菌 $(\mathrm{H}-7, \mathrm{H}-34) \cdots \cdots 2$ 株

真性火落菌（H-1, S-14, S-24, S-32, 9006）

\section{1-2. 集殖培養}

山崎 ${ }^{7)}$ の清酒肝片培地（アルコール 15.5〜16.5\%，市 販一級酒を使用し，塩化鉄反応によりサリチル酸の添加 されていない事を確認) $100 \mathrm{ml}$ を $200 \mathrm{~m} l$ 容隇菌三角フ ラスコ 7 本に用意して，拉の沶のの菌株を一白金耳ずつ 接種し $30^{\circ} \mathrm{C}$ で 2 週間培養した。接種 菌は穿刺培養 (SI 培地)していたもの を使用した。

\section{1-3. 前培養}

清酒肝片培地に培養した，火落菌培 養液 $10 \mathrm{~m} l$ を市販 1 級酒（無サリチル 酸） $1,000 \mathrm{~m} l$ に接種し, $30^{\circ} \mathrm{C}$ で 2 日 間培養し,この液を濾過試料液とした。

1-4. 濾過試験使用器具

使用フィルター：GE-60, GE-40, GE-20 おの拈の $47 \mathrm{~mm}$ 径

使用フィルターホルダー：H $047 \mathrm{~A}$ $00 *$

加圧ポンプ：ゲルマン社 Little Giant model 13152

圧力タンク：ミリポア社X X6700055 1-5. 濾過試験

先に調製した濾過試料液 $100 \mathrm{ml}$ を フィルターを装置したまま $120^{\circ} \mathrm{C}, 20$ 分間のオートクレーブ殺菌を施したフ ィルターホルダー中に無菌的に取り, 30 psi** 执よび 40 psi の 2 種圧力で 加圧濾過を行なった。これらの加熱, 加圧処理によるフィルターの伸縮, 破 劯等の変化は認められなかった。

\section{1-6. 火落菌菌数測定}

加圧濾過によって得れれた濾液を $200 \mathrm{ml} l$ 容三角フラスコ（殺菌済）に無

* 北興化学工業株式会社製作

** 1b/inch ${ }^{2}$ の略号

***捕菌率 $(\%)=\left(1-\frac{\text { 滤液中の菌数 }}{\text { 試料液中の菌数 }}\right) \times 100$
菌的に取り, その中の火落菌数を SI-培地 (Difco bacto agar $1.0 \%$ 添加)を用いた寒天希釈法で測定した。また 濾過試料液も同様の方法で菌数を測定し濾液中の菌数と の比を以って捕菌率***とした。

菌数測定を行なった滤液は直ちに殺菌済の $50 \mathrm{~m} l$ 容三 角フラスコ 3 個にそれぞれ 30 35 ml ずつ分注し, ゴム 栓を施し密封状態で $30^{\circ} \mathrm{C}$ に於いて保存し, 保存 1 ケ月 後, 2 ケ月後および 3 ケ月後の火落菌の増殖を調查する 為の試料とした。

試験は各々の菌株, 圧力条件でそれぞれ 3 回ずつ行な った。結果は第 1〜4 表に示される。2 種の火落性乳 酸菌 H-7 および H-34 株は第 2 表で示されるように, GE-40, GE-20 のフィルターでは 100\% 捕菌され, そ の後 3 ケ月間たっても火落菌の生育, 増殖は認められな

第1表 H-1 True hiochi lactobacilli

\begin{tabular}{|c|c|c|c|c|c|c|c|c|c|c|c|c|c|}
\hline \multirow{3}{*}{ フォィル } & \multirow{3}{*}{$\begin{array}{l}\text { 濾過压 } \\
\text { (ps i) }\end{array}$} & \multirow{3}{*}{$\begin{array}{c}\text { 試料液中 } \\
\text { の生菌数 } \\
=/ \mathrm{m} l\end{array}$} & \multirow{3}{*}{$\begin{array}{l}\text { 濾液中の } \\
\text { 生菌数 } \\
=/ \mathrm{m} l\end{array}$} & \multirow{3}{*}{ 捕菌率* } & \multicolumn{9}{|c|}{ 滤過 1 〜 3 ケ月後の滤液中の増菌** } \\
\hline & & & & & \multicolumn{3}{|c|}{1 ケ月後 } & \multicolumn{3}{|c|}{2 ケ月後 } & \multicolumn{3}{|c|}{3 ケ月後 } \\
\hline & & & & & $\overparen{I}$ & II & III & I & II & III & $\overparen{I}$ & III & III \\
\hline & $30\left\{\begin{array}{l}1 \\
2 \\
3\end{array}\right.$ & $\begin{array}{l}5.7 \times 10^{5} \\
7.6 \times 10^{5} \\
5.6 \times 10^{5}\end{array}$ & $\begin{array}{l}6.3 \times 10^{4} \\
4.1 \times 10^{4} \\
4.3 \times 10^{4}\end{array}$ & $\begin{array}{l}88.95 \\
94.61 \\
92.32\end{array}$ & $\underline{-}$ & $\frac{H}{-}$ & \pm & $\frac{\text { 册 }}{-}$ & 曲 & I & $\frac{H}{-}$ & \pm & $\frac{+}{-}$ \\
\hline$\Delta-00$ & $40\left\{\begin{array}{l}1 \\
2 \\
3\end{array}\right.$ & $\begin{array}{l}5.7 \times 10^{5} \\
7.6 \times 10^{5} \\
5.6 \times 10^{5}\end{array}$ & $\begin{array}{l}7.1 \times 10^{4} \\
5.2 \times 10^{4} \\
5.9 \times 10^{4}\end{array}$ & $\begin{array}{l}87.54 \\
93.16 \\
89.46\end{array}$ & $=$ & I & IIt & $\frac{H}{-}$ & $\overline{-}$ & III & \pm & - & $\frac{\text { Ht }}{-}$ \\
\hline & $30\left\{\begin{array}{l}1 \\
2 \\
3\end{array}\right.$ & $\begin{array}{l}5.7 \times 10^{5} \\
7.6 \times 10^{5} \\
5.6 \times 10^{5}\end{array}$ & $\begin{array}{l}0 \\
1.5 \\
1.5\end{array}$ & $\begin{array}{l}100 \\
99.99 \\
99.99\end{array}$ & $\begin{array}{l}- \\
-\end{array}$ & $=$ & $\underline{-}$ & $\underline{-}$ & $\begin{array}{l}- \\
-\end{array}$ & $\begin{array}{l}- \\
-\end{array}$ & $\begin{array}{l}- \\
-\end{array}$ & - & $\overline{-}$ \\
\hline 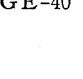 & $40\left\{\begin{array}{l}1 \\
2\end{array}\right.$ & $\begin{array}{l}5.7 \times 10^{5} \\
5.6 \times 10^{5} \\
5.6 \times 10^{5}\end{array}$ & $\begin{array}{l}4.5 \\
0.5 \\
2.5\end{array}$ & $\begin{array}{l}99.99 \\
99.99 \\
99.99\end{array}$ & $\begin{array}{l}- \\
-\end{array}$ & $\bar{z}$ & $=$ & $\begin{array}{l}- \\
-\end{array}$ & $\begin{array}{l}- \\
-\end{array}$ & $\begin{array}{l}- \\
-\end{array}$ & $\overline{-}$ & $\bar{z}$ & $\overline{-}$ \\
\hline & $30\left\{\begin{array}{l}1 \\
2 \\
3\end{array}\right.$ & $\begin{array}{l}5.7 \times 10^{5} \\
7.6 \times 10^{5} \\
5.6 \times 10^{5}\end{array}$ & $\begin{array}{l}0 \\
0 \\
0\end{array}$ & $\begin{array}{l}100 \\
100 \\
100\end{array}$ & $\begin{array}{l}- \\
-\end{array}$ & I & $\begin{array}{l}- \\
-\end{array}$ & $\begin{array}{l}- \\
-\end{array}$ & $\begin{array}{l}- \\
-\end{array}$ & $\begin{array}{l}- \\
-\end{array}$ & $\overline{-}$ & $\underline{-}$ & $\begin{array}{l}- \\
-\end{array}$ \\
\hline & $40\left\{\begin{array}{l}1 \\
2 \\
3\end{array}\right.$ & $\begin{array}{l}5.7 \times 10^{5} \\
7.6 \times 10^{5} \\
5.6 \times 10^{5}\end{array}$ & $\begin{array}{l}0 \\
0 \\
0\end{array}$ & $\begin{array}{l}100 \\
100 \\
100\end{array}$ & $\begin{array}{l}- \\
-\end{array}$ & $=$ & $=$ & I & $\begin{array}{l}- \\
-\end{array}$ & - & $\overline{-}$ & I & $\bar{z}$ \\
\hline
\end{tabular}

* $\left(1-\frac{\text { 畡液中の生菌数 }}{\text { 試料液中の生菌数 }}\right) \times 100 \%$

** 生菌数 $(=/ \mathrm{m} l) \quad-: 0,+: \sim 10,+1: \sim 10^{2}$, 冊: 104 以上

第2表 H-7 特よび H-34 Hiochi lactobacilli

\begin{tabular}{|c|c|c|c|c|c|c|c|c|c|c|}
\hline \multirow{3}{*}{ フォィル } & \multirow{3}{*}{$\begin{array}{l}\text { 滤過压 } \\
\text { (ps i) }\end{array}$} & \multirow{2}{*}{$\begin{array}{l}\text { 試料液中 } \\
\text { の生菌数 }\end{array}$} & \multirow{2}{*}{$\begin{array}{l}\text { 熟液中の } \\
\text { 生菌数 }\end{array}$} & \multirow[b]{2}{*}{ 捕菌率 } & \multicolumn{6}{|c|}{ 滤過 1 〜 3 ケ月後の滤液中の增菌 } \\
\hline & & & & & \multicolumn{2}{|c|}{$\overbrace{}^{1 \text { ケ月後 }}$} & \multicolumn{2}{|c|}{2 ケ月後 } & \multicolumn{2}{|c|}{3 ケ月後 } \\
\hline & & $(\exists / \mathrm{m} l)$ & $(\exists / \mathrm{m} l)$ & $(\%)$ & I & III & I & II III & I & II III \\
\hline & $30\left\{\begin{array}{l}1 \\
2 \\
3\end{array}\right.$ & $\begin{array}{l}1.2 \sim 6.0 \times 10^{5} \\
1.7 \sim 4.3 \times 10^{5} \\
2.0 \sim 6.1 \times 10^{5}\end{array}$ & $\begin{array}{l}0 \sim 1.5 \\
0 \sim 0.5 \\
0 \sim 1.5\end{array}$ & $\begin{array}{l}99.99 \sim 100 \\
99.99 \sim 100 \\
99.99 \sim 100\end{array}$ & $\overline{-}$ & $\bar{z}$ & $\overline{-}$ & $\bar{z}$ & $\begin{array}{l}- \\
- \\
-\end{array}$ & $=$ \\
\hline & $40\left\{\begin{array}{l}1 \\
2 \\
3\end{array}\right.$ & $\begin{array}{l}1.2 \sim 6.0 \times 10^{5} \\
1.7 \sim 4.3 \times 10^{5} \\
2.0 \sim 6.1 \times 10^{5}\end{array}$ & $\begin{array}{l}2.5 \sim 4.0 \\
0 \sim 0.5 \\
0 \sim 1.5 \times 10^{2}\end{array}$ & $\begin{array}{l}99.99 \\
99.99 \sim 100 \\
99.98 \sim 100\end{array}$ & $\begin{array}{l}- \\
-\end{array}$ & $\bar{z}$ & $\bar{z}$ & $\bar{z}$ & $\begin{array}{l}- \\
\overline{-}\end{array}$ & $=$ \\
\hline & & $\begin{array}{l}1.2 \sim 6.0 \times 10^{5} \\
1.7 \sim 4.3 \times 10^{5} \\
2.0 \sim 6.1 \times 10^{5}\end{array}$ & $\begin{array}{l}0 \\
0 \\
0\end{array}$ & $\begin{array}{l}100 \\
100 \\
100\end{array}$ & $\begin{array}{l}- \\
-\end{array}$ & $\begin{array}{l}- \\
-\end{array}$ & $\begin{array}{l}- \\
-\end{array}$ & $E=$ & $\begin{array}{l}- \\
-\end{array}$ & $\bar{I}=$ \\
\hline & $40\left\{\begin{array}{l}1 \\
2 \\
3\end{array}\right.$ & $\begin{array}{l}1.2 \sim 6.0 \times 10^{5} \\
1.7 \sim 4.3 \times 10^{5} \\
2.0 \sim 6.1 \times 10^{5}\end{array}$ & $\begin{array}{l}0 \\
0 \\
0\end{array}$ & $\begin{array}{l}100 \\
100 \\
100\end{array}$ & $\begin{array}{l}- \\
-\end{array}$ & - & $\bar{z}$ & $=$ & $=$ & $=$ \\
\hline & $30\left\{\begin{array}{l}1 \\
2 \\
3\end{array}\right.$ & $\begin{array}{l}1.2 \sim 6.0 \times 10^{5} \\
1.7 \sim 4.3 \times 10^{5} \\
2.0 \sim 6.1 \times 10^{5}\end{array}$ & $\begin{array}{l}0 \\
0 \\
0\end{array}$ & $\begin{array}{l}100 \\
100 \\
100\end{array}$ & $\bar{z}$ & $=$ & $\bar{z}$ & $=-$ & $=$ & - \\
\hline & $40\left\{\begin{array}{l}1 \\
2 \\
3\end{array}\right.$ & $\begin{array}{l}1.2 \sim 6.0 \times 10^{5} \\
1.7 \sim 4.3 \times 10^{5} \\
2.0 \sim 6.1 \times 10^{5}\end{array}$ & $\begin{array}{l}0 \\
0 \\
0\end{array}$ & $\begin{array}{l}100 \\
100 \\
100\end{array}$ & $\begin{array}{l}- \\
-\end{array}$ & -- & & 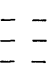 & & $\overline{-}$ \\
\hline
\end{tabular}


鈴木・松岡・土崎・斉藤：メンブランフィルターによる清酒火落菌の濾過除菌について

第3 表 S-14 抒よび S-34 True hiochi lactobacilli

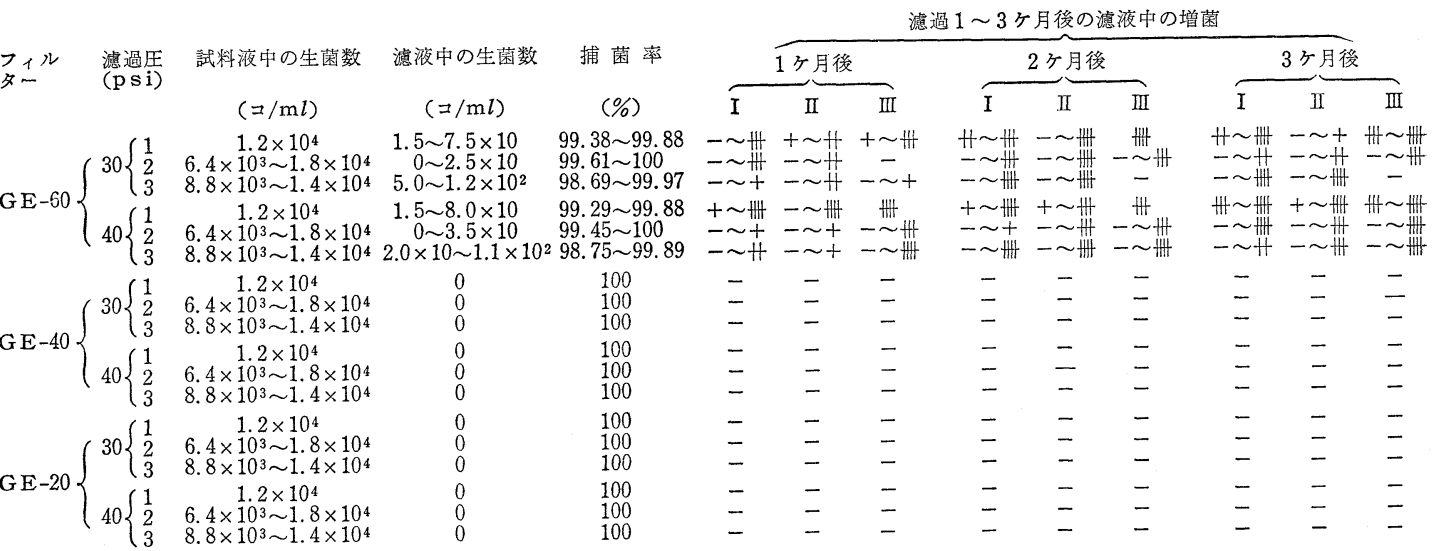

第 4 表 S-24 おょよ゙ 9006 True hiochi lactobacilli

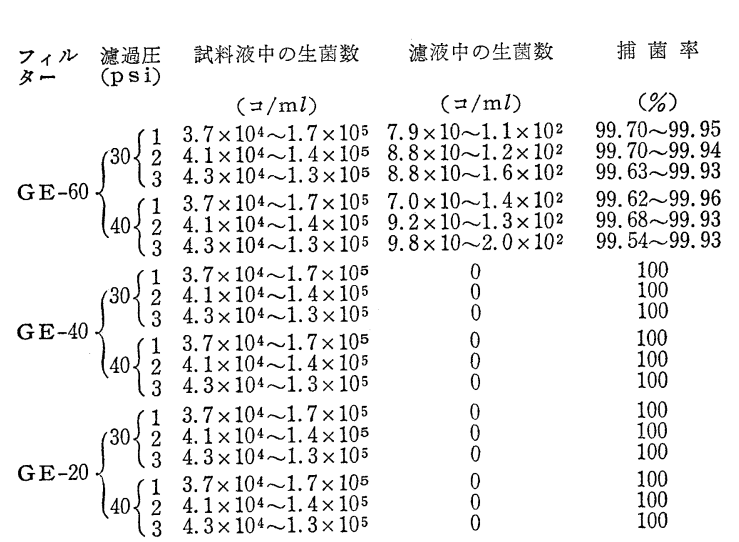

かった。GE-60 のフィルターはH-7 株に対し $30 \mathrm{psi}$ の 圧力下では $100 \%$ 捕菌したが, $40 \mathrm{psi}$ の圧力下では 3 回の試験のうち 1 回だけ通過を許した $\mathrm{H}-34$ 株に刘して は 30 特よび 40 psi の圧力下で 3 回の試験とも通過を許 したが，菌通過濾液を $30^{\circ} \mathrm{C} て ゙ 1$ ケ間保存した結果, 保存濾液中には火落菌は認められず, 2 ケ月特よび 3 ケ 月後も同様に火落菌は存在しなかった。

5 株の真性火落菌, H-1, S-14, S-24, S-34 和上 び 9006 は各々第 1,3 表打よび第 4 表に示される。GE -20は 5 菌株とも 100\% の捕菌率を示した。GE-40は $\mathrm{H}-1$ 株を除いて他の 4 株を $100 \%$ 捕菌した。通過した $\mathrm{H}-1$ 株も濾液 $1 \mathrm{~m} l$ 当り $0 \sim 4.5$ 個認められたにすぎ ず，捕菌率は平均 $99.9999 \%$ を示している。 $30^{\circ} \mathrm{C}$ 保存 1〜3 ケ月後にはその生育, 增殖は認められなかった。 GE-60は 5 株真性火落菌のすべての通過を許し, 濾過除 菌としての実用には供し難いものであった。保存 $1 \sim 3$ ケ月後の增菌状態は同一菌株, 同一試験区間に於いても バラつきの多いものとなり, 火落現象の複雑さを物語っ ている。 滤過 $1 \sim 3$ ケ月後の滤液中の增菌

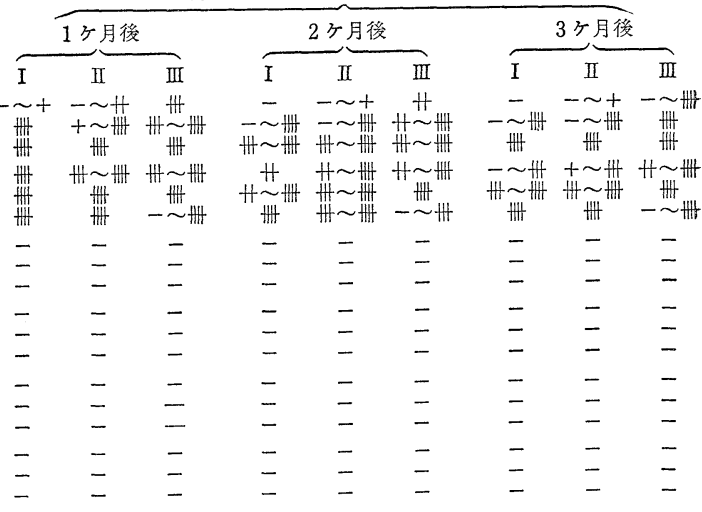

\section{2. 濾過流量試験}

滤過除菌試験に供した $100 \mathrm{~m} l$ の試料液を濾過するの に要した時間を測定し，NPフィルター濾過有効面積当 りの濾過流量飞換算した*。

結果は第 5 表に示す如くである。GE-20 の濾過流量は GE-40の招よそ6 分の 1 であり，濾過の経済性より考元 ると実用には供し難い。GE-40 は特よそ70１20 mll $\mathrm{cm}^{2} / \mathrm{min}$ の濾過流量を示し十分実用に供し得るもので ある。また GE-60 は火落菌の通過があり実用性はそし いが比較の為に記した。

第 5 表 濾過流量試験 (単位: $\mathrm{m} l / \mathrm{cm}^{2} / \mathrm{min}$ )

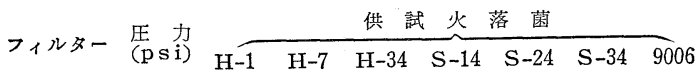
GE-20 $\left\{\begin{array}{llllllll}30 & 11.0 & 13.7 & 16.2 & 15.8 & 15.9 & 14.0 & 15.3 \\ 40 & 15.0 & 19.8 & 19.8 & 19.8 & 23.4 & 16.2 & 18.3\end{array}\right.$ $\mathrm{GE}-40 \quad\left\{\begin{array}{rrrrrrrr}30 & 67.0 & 97.0 & 107.9 & 74.7 & 74.7 & 77.7 & 77.7 \\ 40 & 92.5 & 97.0 & 121.4 & 92.0 & 102.2 & 92.5 & 84.4\end{array}\right.$ GE-60 $\left\{\begin{array}{rrrrrrrr}30 & 48.5 & 129.5 & 121.4 & 176.5 & 121.4 & 71.9 & 129.5 \\ 40 & 60.7 & 176.5 & 176.5 & 277.4 & 138.7 & 84.4 & 176.5\end{array}\right.$

* N Pフィルターの濾過有効面積はサポートスクリー ンの開孔率に依存する。今試験に供したサポートス クリーンの開孔率は $32.16 \%$ である。 
濾過圧力による流量はやはり $30 \mathrm{psi}$ よりも $40 \mathrm{psi}$ の 方が $20 \sim 30 \%$ 勝っていた。濾過試料液中の火落菌数は $10^{3} \sim 10^{5}$ 個 $/ \mathrm{ml}$ であるが菌濃度による濾過流量の差異は, この程度の濃度では認められないと推測される。 $\mathrm{H}-1$ 株 扣よびS-34 株に於いて GE-40 と GE-60 の濾過流量が 逆転して，GE-60の方が少なくなっている。これは菌が フィルターの孔を通過する時の抵抗ないしは目詰りと考 えられる。GE-60 を通過するが GE-40 との流量逆転が ないのは S-14, S-24 㧊よび 9006 の 3 株である。これ ら 3 株は $\mathrm{H}-1$ 物よび $\mathrm{S}-34$ の 2 株より大きな菌である事 飞注目すると前記 3 株は濾過時にケーキ濾過的現象を呈 していると考兄らる。

\section{3. 物性試験}

3-1. 使用フィルター

GE-20 特よび GE-40 の 2 種

3-2. 試料清酒

調合濾過後 1 級原酒 2 種, 試料- $\mathrm{A}$ 抒よび試料 $-\mathrm{B}$

3-3. 分析項目

日本酒度, アルコール度, 酸度, アミノ酸度, 色度 $(430$ $\mathrm{m} \mu)$, 濁度拉よび比重

3-4. 分析方法

国税庁所定分析法 ${ }^{48)}$ に従った。

3-5. 結果-1（GE-40亿よる濾過）

第 6 表拉よび第 7 表に示されるように GE-20 による

\begin{tabular}{|c|c|c|c|c|c|c|c|}
\hline & 第 6 表 & 物性 & 試験 & （試精 & 淤 & A) & \\
\hline & 日本酒度 & $\begin{array}{l}\text { アルa } \\
-\mu \\
(\%)\end{array}$ & $\begin{array}{l}\text { 総酸 } \\
(\mathrm{m} l)\end{array}$ & $\begin{array}{l}\text { ア 酸 } \\
\text { (ml) } \\
(\mathrm{m} l\end{array}$ & 濁度 & 色度 & 比重 \\
\hline 無 処 理 & -7.7 & 19.2 & 1.80 & 1.85 & 0 & 0.017 & 1.0065 \\
\hline$E-40$ 㴔過 -1 & -7.7 & 19. 2 & 1.80 & 1.80 & 0 & 0.014 & 1.0064 \\
\hline-2 & -7.7 & 19.2 & 1.80 & 1. & 0 & 0.014 & 1.0065 \\
\hline-3 & -7.7 & 19.1 & 1.80 & 1. & 0 & 0.015 & 1.0065 \\
\hline-4 & -7.7 & 19.1 & 1.80 & 1.80 & 0 & 0.014 & 1.0065 \\
\hline
\end{tabular}

第 7 表 物性試験（試料清酒-B）

\begin{tabular}{|c|c|c|c|c|c|c|c|}
\hline & 日本酒度 & $\begin{array}{l}\text { アルa } \\
-\mu \\
(\%)\end{array}$ & $\begin{array}{l}\text { 総酸 } \\
(\mathrm{m} l)\end{array}$ & $\begin{array}{l}\text { アミ } \\
\text { 酸 } \\
(\mathrm{ml})\end{array}$ & 濁度 & 色度 & 比重 \\
\hline 無 処 理 & -6.6 & 20.1 & 1.95 & 2.0 & 0 & 0.046 & 1.0055 \\
\hline $\begin{array}{c}\mathrm{GE}-40 \text { 滤過-1 } \\
\quad / "-2\end{array}$ & $\begin{array}{l}-6.6 \\
-6.6\end{array}$ & $\begin{array}{l}20.1 \\
20.1\end{array}$ & $\begin{array}{l}1.95 \\
1.95\end{array}$ & $\begin{array}{l}2.0 \\
2.0\end{array}$ & $\begin{array}{l}0 \\
0\end{array}$ & $\begin{array}{l}0.046 \\
0.046\end{array}$ & 1. 0057 \\
\hline
\end{tabular}

第 10 表 官 能
濾過処理では 6 種分析項目間に差異があるとは認められ ない。

$$
\text { 3-6. 結果-2（GE-20 に上る濾過） }
$$

第 8 表および第 9 表に示されるように GE-20 による 濾過処理では日本酒度に若干のバラつきが見られる程度 でその他は殆ど変化が無いとい党る。

以上の結果よりNPフィルター濾過処理による清酒の 物性的変化は無視し得る程, 少ないと考劣て良い。

\section{4. 官能試験}

官能試験（唎酒）は総合, 香り, 味の濃さ执よび色の 4 項目について行なった。判定した 5 氏による結果は第 10 表の如くである。表より明らかなように総合的な酒質 についてみるとバラッキが大きい，この原因はフィルタ 一によるものなのか, 古るい性濾過器具を使用した事に よるるのか断定は難かしいと思われる。すなわち味の濃 さについて平均値の上で比較してみると無処理に比べ差 があるとは考兄られず, バラッキも少ない。反面, 香り

（ゴム臭として考觉たもの）は全体としてみると処理後 には必ずその点数が高くなって物り, 又その点数の大き いもの活ど酒質の点数も高くなっている。これらの事を 考慮した場合, 酒質のバラッキは香り（ゴム臭）のバラ ッキ具合とかなり類似して和り, 濾過する事以より酒質 が劣下するのではなく, 濾過の時に使用するゴム管等に

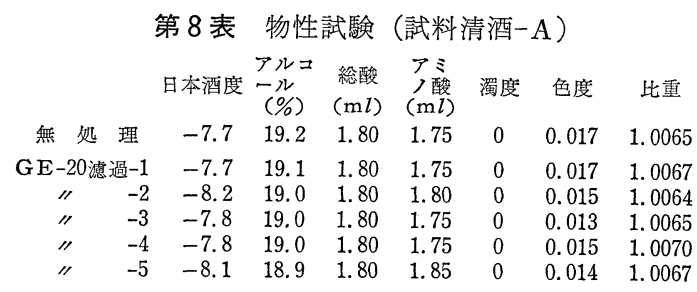

\begin{tabular}{|c|c|c|c|c|c|c|c|}
\hline & 第 9 表 & 物性 & 試験 & （試料 & 青酒一 & & \\
\hline & 日本酒度 & $\begin{array}{l}\text { アル } \\
-\mu \\
(\%)\end{array}$ & $\begin{array}{l}\text { 総酸 } \\
(\mathrm{m} l)\end{array}$ & 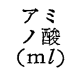 & 濁度 & 色度 & 此重 \\
\hline 無 処 理 & -6.6 & 20.1 & 1.95 & 2.00 & 0 & 0.046 & 1.0055 \\
\hline $\begin{array}{c}\mathrm{GE}-20 \text { 濾過-1 } \\
-2\end{array}$ & $\begin{array}{l}-7.0 \\
-7.2\end{array}$ & $\begin{array}{l}19.9 \\
19.8\end{array}$ & $\begin{array}{l}1.95 \\
1.90\end{array}$ & 2.05 & $\begin{array}{l}0 \\
0\end{array}$ & 0.046 & 1. 0058 \\
\hline
\end{tabular}

能 試 験 結 果
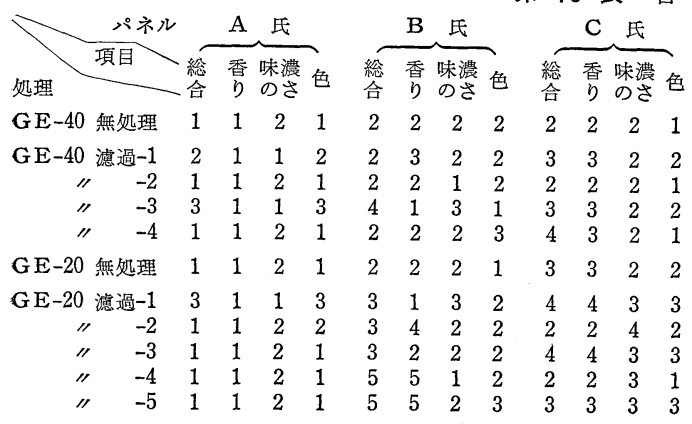

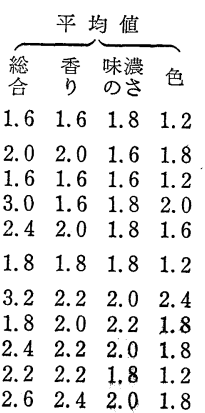


起因すると考皃た方が無難であると思われる。ゴム管部 分を無くすれば使用に際し問題がないといって良い。 又, 色度 (肉眼的) 飞も少々バラッキが見られるが，物 性試験の分光光度計の色度の上からは殆んど差は見られ なく唎猪口の差によるものと考它られる。

\section{総括および考察}

1. GE-40 は唯一の例外を除いて 100\% 火落菌を捕 捉し, かつ濾過流量は GE-20 の約 6 倍であり 経済性等 を考慮すると GE-20 よりも実用に供し得るるのである。

2. H-1 株は GE-40 を若干通過したが捕菌率は和よ そ $99.9999 \%$ で㐫り, かつ 1 3 ケ月後の生育, 増殖は 認められなかった。この事は必ずしも100\%の捕菌でな くとも良い事を示している。

3. 火落性乳酸菌は $30^{\circ} \mathrm{C}$ 保存 1 ケ月後には存在しな かった。これは清酒の火落ちに関与するのは殆んぞが真 性火落菌であるとの考劣を実証している。

4. N P ィルターによる濾過除菌処理は清酒の物性 的変化特よび官能的変化何ら関与しないと言兄る。

\section{文献}

1) Atkinson : Mem.Tokyo Imp. Univ.Sci.Dep., 6, 1 (1881)

2) 鳥居 : 䤋試報, 2, 30 (1901)

3) 鳥居: 本誌, 1(7), 23 (1906)

4) 高野: 本誌, 1(1), 17 (1906)
5) 高橋, 善田 : 醕陚報, 59,1 (1915)

6) 11) 山崎：農化, $1,475(1925) ； 5,377(1929) ; 5,399 ; 5,481$ : 8, $991(1932) ; 8,1111$

12) 16) 大谷(義) :J.Fac.Agr. Hokkaido Imp. Unvv., : 39, 1064 (1932) : 醇学, 11, 9(1933); 11, 15; 11, 772;12, 19(1934)

17), 18) 松山：農化, $28,418(1954): 28,422$

19) 21) 北原, 金子, 後藤：J.Gen. Apll. Microbiol., : 2, 431 (1956) ; 3, 102(1957) : 3, 111

22), 23) 田村, 名倉：農化, 32, 701, 707 (1958)

24) 田村, 铃木; 譨化, 32, 778 (1958)

25) 田村；農化, 32, 783 (1958)

26）野白喜久雄 $:$ 本誌，64, 109 (1969)

27）野白喜久雄, 百瀬洋夫; 本誌, 65, 715 (1970)

28) 百瀬洋夫, 野白喜久雄, 山岸敏朗 : 本誌, 65, 799 (1970)

29) 31）百瀬洋夫，野白喜久雄；本誌，65，999(1970)；65，1108；66 $271(1971)$

32) 吉田; 本誌, 33,446 (1938)

33) 風間, 市川: 本誌, 57,413 (1962)

34) 橋田, 寺本, 向井: 䣹工, 36, 49 (1959)

35) 黒野, 岩下, 鳥山：酸試報, 117, 1 (1933)

36) 黒野, 醉試報, 119,37 (1934)

37) 滰沢, 田中: 醇試報, 127, 41 (1938)

38) 田中, 川北 : 酶工, 29,393 (1951)

39) 谷, 翼, 酸工, 36,365 (1958)

40) 中村, 城: Bull.Agr.Chem.Soc. Japan, 32, 445(1958)

41) 寺本, 大塚, 橋田; 本誌, 48, 200 (1953)

42) 野坂, 村上; 醴工, 45, 756 (1967)

43) 伊野本, 橋田, 大塚; 酸工, 29, 204 (1951)

44) 寺本, 橋田; 醱工, 31,376 (1953)

45) 守, 村井, 山田; 本誌, 65, 703 (1970)

46) 吉田: 本誌, 33, 446 (1938)

47) 清酒技術者会, 清酒保全研究会; 本誌, 65, 632 (1970)

48) 国税庁所定分析法注解 (1967)

J. Soc. Brew. Japan, 1972, Vol.67, No.2, p.137 p. 141

\title{
A Filtering Sterilization of Japanese Saké by Membrane Filter
}

\author{
by
}

Meiji Suzuki*, Masayuki Matsuoka, Minami Tsuchizaki, Yutaka Saito

(Central Research Laboratories of Hokko Chemical Industry Co. Ltd.)

A filtering sterilization of Japanese saké was tested by using of Nuclepore $\otimes$ membrane filters, 0.6 $\mu, 0.4 \mu$, and $0.2 \mu$ pore size respectively. Seven strains, H-1, H-7, H-37, S-14, S-24, S-34 and 9006 were used as test organisms.

Using the $0.4 \mu$ and $0.2 \mu$ pore size filter, all test organisms were retained on its filter and Hiochi bacteria did not observed after 3 months incubation at $30^{\circ} \mathrm{C}$. On the otherhand, all test organisms passed through the $0.6 \mu$ pore size filter.

The Nuclepore $\bigotimes$ membrane filters $0.4 \mu$ and $0.2 \mu$ pore size were enough to use for filtering sterilization of Hiochi bacteria in Japanese saké.

The changes of saké components after filtering sterilization were not proved during this treatment.

* Tokyo Agr. Univ. 